\title{
LA ESTRUCTURA SOCIAL QUITEÑA ENTRE 1737 y 1745 SEGÚN EL PROCESO CONTRA JOSÉ DE ARAUJO
}

\author{
POR \\ LUIS J. RAMOS GOMEZ \\ Departamento "Historia de América II" \\ Universidad Complutense (Madrid)
}

Una de las piedras angulares de la historia del espacio quiteño se colocó en 1739 cuando, por una parte, ese ámbito salió de la órbita de Lima para incorporarse al nuevamente creado virreinato de La Nueva Granada, y, por otra, el ataque inglés de 1739 y 1740 sobre el istmo de Panamá terminó con las ya poco frecuentes ferias de Portobelo al destruirse esta población y Chagres. Estos acontecimientos tan trascendentales no se produjeron en un momento en el que la quietud o el sosiego reinaran en Quito, pues la ciudad vivía entonces inmersa en una sorda e intensa lucha por el poder local que tuvo como resultado más llamativo el procesamiento y deposición del presidente de la Audiencia Don José de Araujo y Río, natural de Lima, quien había sido nombrado para el cargo el 9 de abril de 1732 tras la entrega de un donativo de 26.000 pesos.

Aunque el proceso puede ser contemplado como una reacción contra la actuación del presidente al frente del gobierno, sin embargo nosotros creemos que sólo es un acto del enfrentamiento existente en Quito por el control del poder en ese ámbito, y que su análisis nos arrojará mucha luz sobre este tema así como sobre los miembros de los bloques enfrentados y su estructura interna. Evidentemente el llegar a este resultando no es tarea fácil ni rápida, sobre todo cuando la fuente principal con la que contamos es un proceso tan extenso y complejo como el del

Sigla UTIL.IZ.ADA:

AGI: Archivo General de Indias (Sevilla). 
presidente Araujo (1); por ello no puede extrañar que no estemos todavía en condiciones de aportar resultados concretos, y que tengamos que conformarnos en este artículo con presentar la estructura global del proceso y una serie de elementos que fundamentan nuestro enfoque.

\section{LAS DENUNCIAS DE 1736 Y 1737}

En 1737 comenzaron a llegar a España varios escritos procedentes de Quito en los que se plasmaban una serie de acusaciones contra la actuación de Don José de Araujo y Río, quien el 28 de diciembre de 1736 había tomado posesión del puesto de gobernador y capitán general, y al día siguiente el de presidente de la Real Audiencia; también se hacía cargo entonces del juicio de residencia de su predecesor, Don Dionisio de Alcedo y Herrera, quien, libre de culpas, partía hacia España en octubre de ese año (2).

En esos momentos iniciales del mandato de Araujo - diciembre de 1736- están fechados los primeros escritos contra él, los cuales van firmados por dos personas de indudable calidad y peso: don Dionisio de Alcedo y Herrera, su predecesor, y Don Lorenzo de Nates, diputado del comercio quiteño. El primero decía al Rey el 31 de diciembre de 1736 que el nuevo presidente parecía traer mercancía ilícita en su equipaje, formado por 66 cargas que viajaban inmediatas a su sombra, y por 130 más que

(1) Este proceso tiene concentrado el principal de su información en la sección Escribanía de Cámara del Archivo General de Indias, legajos 914 a, b y c 915 a y c; y 916 a y b, si bien también hay elementos importantes en las secciones de Indiferente General y Audiencias de Quito y Lima; las citas y datos que aportamos en el presente artículo, salvo indicación contraria, han sido tomados de los legajos de Escribanía de Cámara.

De este poco utilizado pleito se ocupó ya Federico González SuÁrez en su obra Historia General de la República del Ecuador, reeditada en tres volúmenes en Quito, por la Casa de La Cultura Ecuatoriana, 1969-70 (págs 1.007 y ss.), y nosotros mismos en diversos apartados del volumen primero de Epoca, génesis, y texto de las "Noticias Secretas de América", de Jorge Juan y Antonio de Ulloa, vols. XVI y XVII de la colección "Tierra nueva e cielo nuevo", Madrid, C. S. I. C., 1986.

(2) La residencia de Alcedo se le había encomendado a Araujo el 13 de abril de 1734; se cerró el 9 de agosto de 1737, absolviéndosele el 29 de los tres cargos que se le sustanciaron. 
le habían antecedido; éstas habían entrado a plena luz del día en Quito, y por ello la ciudad había sido testigo de la llegada de diversos botijambres y planchas de plomo, y de que muchos bultos se habían guardado en tiendas de mercaderes. El segundo escrito contra Araujo iba firmado por Lorenzo de Nates el 29 de diciembre de 1736, y en él el diputado del comercio quiteño se quejaba de esa introducción efectuada por el nuevo presidente y hacía saber al Rey que los comerciantes locales habían resuelto «no bajar ninguno a Cartagena, aunque vengan noticias de estar ya allí los galeones» a fin de no dejar "a sus espaldas una barata» que provocase su ruina.

Pero estas cartas no iban a ser las únicas denuncias contra Araujo, ni la introducción de comercio ilícito el único cargo hecho al nuevo presidente, pues a manos del Consejo de Indias también llegaron otros escritos con distintas acusaciones que parecían demostrar un inaudito comportamiento por parte de la cabeza del espacio quiteño. La primera denuncia refería un hecho que tuvo lugar a los cinco días de su entrada en Quito, en concreto el día primero de enero de 1737; en esa fecha, cuando los miembros del cabildo de la ciudad pasaron a pedir la correspondiente venia a Araujo para efectuar la elección de alcaldes, fueron presionados por éste para que votasen a dos personas cuyos nombres les indicó; no se doblegó el cabildo a la voluntad del presidente, por lo que éste optó por desestimar la elección hecha por la mayoría de los capitulares (3), y dar el puesto a sus candidatos: Don Joaquín Laso de la Vega y Don Tomás Guerrero (4).

Pero no paró ahí la actuación de Araujo, ya que de inmediato comenzó a presionar sobre los miembros del cabildo que le habían sido contrarios, a quienes tachó de "faccionistas y cabezas de bando", rechazó su presencia e intentó por todos los medios a su alcance que no pudiesen obtener testimonio de lo sucedido o de su buen nombre, para lo cual no dudó en perseguir a los escribanos que apoyaran a los regidores. También procuró descabezar la resistencia que pudieran hacerle sus oponentes desde estructuras que ellos dominaban, para lo cual buscó el destierro,

(3) Estos habían elegido a Juan Ponce de León, Conde de Selva Florida, y a Don Antonio Pastrana.

(4) Sobre este tema vid. Luis J. Ramos Gómez: “Un ejemplo de la lucha por el poder en Quite (la elección de alcaldes del año de 1737)", en Cultura Revista del Banco Central del Ecuador, vol. 24 A (enero-abril de 1986), Quito, 1989. 
mediante un Real Acuerdo celebrado el 8 de enero (5), del regidor decano José Hidalgo de Pinto y consiguió destituir a otro regidor, Simón Alvarez Monteserín, del puesto de justicia mayor interino, cargo que ocupaba desde el 15 de agosto de 1736 tras la muerte de Nicolás Ponce.

La situación planteada fue conocida en la Corte (6) gracias a una serie de escritos remitidos desde Quito por los afectados, de los cuales el primero en el tiempo fue el del depuesto justicia mayor, Simón Alvarez de Monteserín, quien en momentos tan tardíos como el 28 de febrero de 1737 se quejaba de todo lo por él padecido en general, y en particular de la pérdida de la vara de alcalde mayor; a este documento se sumaba el que el 8 de marzo escribían los agraviados regidores quiteños (7) denunciando los hechos.

Pero no sólo llegaron a las Cortes estas misivas, pues les sucedieron otras con nuevos cargos y firmantes, como las del fiscal de la Audiencia, don Juan de Valparda y. de la Ormaza, y las de uno de los dos Oficiales Reales, el contador Don José Suárez de Figueroa, personas ambas de gran relieve al pertenecer a dos de los organismos claves del espacio quiteño. Si bien de la segunda figura no tenemos ningún dato sobre sus relaciones con el presidente, de Don Juan de Valparda sabemos que había coincidido con Araujo en la Corte, donde habían trabado amistad,

(5) El oidor Manuel Rubio de Arévalo, quien llevó adelante la pesquisa contra Araujo, decía en su informe final de 1745 "que el [Real] Acuerdo con que ahora se abroguela, no fue otra cosa que una conversación privada que por sólo autorizar su intento tuvo en su propia casa el Presidente con los Ministros [de la Audiencia], en la cual sólo indagó sobre la idoneidad de Lasso y de Guerrero, afectando misterios [y] encargos del Virrey de Lima, sin que concurriese escribano de cámara ni otro subalterno ni se escribiese el tal acuerdo hasta pasados ocho días en que se abrió el despacho de la Audiencia... y que como en el intermedio, habiendo ejecutado tantas tropelias como costan de estos volúmenes, recelase el Presidente que los quejosos hacian sus recursos a los superiores, previno que el día 8 de enero se extendiese en el libro aquella nota que ahora llama [Real] Acuerdo, apoyándole con aquellas mínimas causas que le habían persuadido".

(6) Algunos de los escritos de los que nos ocupamos en éste y en los siguientes párrafos fueron también remitidos a Lima, desde donde obró el Virrey Villagarcía, aunque sin la trascendencia del Consejo.

(7) El 8 de marzo de 1737 denunciaban el hecho Don Simón Alvarez de Monteserín, Don José Hidalgo de Pinto, Don Lorenzo de Nates, Don Lorenzo Díaz de la Madrid, Don Domingo de Andraca, Don José de Herrera, Don Manuel de Alfredo y Oñate y Don Bernardo de Quirós. 
hecho del que había hecho gala Valparda en Quito (8) desde el 28 de febrero de 1736, fecha de su toma de posesión. Sin embargo esta amistad no duró mucho tras el nuevo encuentro, pues a fines de enero de 1737 el fiscal se había alejado tanto de la órbita del presidente que el primero de febrero -inmediatamente después del conocido incidente de Antonio de Ulloa y Jorge Juan con el presidente Araujo, en el que estuvo muy mezclado el fiscal (9)- los alcaldes le abrieron una información, y al poco salía hacia Madrid la primera queja contra su actuación, ya que Araujo escribió al Rey el 22 de febrero acusándole de oponérsele y ser la cabeza de la facción contraria.

La reacción del fiscal no se hizo esperar, pues atacó la actuación del presidente en dos cartas distintas fechadas en un mismo día: el primero de marzo de 1737. En una de ellas Valparda acusaba al presidente de reclutar por su cuenta y riesgo una docena de soldados y de colocar el 14 de febrero un gravamen de cuatro reales al mes sobre los pulperes para afrontar su paga. $\mathrm{Si}$ el hecho de levantar una compañía de soldados era ya de por sí muy grave por no tener competencias para ello, el gravar a los pulperos no le iba a la zaga, aumentando el pecado la circunstancia - denunciada por Valparda- de que "a fin de relevarse los pulperos de la contribución del número impuesto, han cerrado muchos las tiendas, menoscabándose considerablemente el ramo del indulto y composición de pulperías que pertenece al Real Haber de Vuestra Majestad».

En la segunda carta de primero de marzo, el fiscal daba su versión sobre las elecciones de alcaldes introduciendo en el juego una nueva figura: la del Oficial Real tesorero Fernando García Aguado, a quien acusaba de haber sobornado a Araujo con 1.500 pesos para manejar la elección de alcaldes ordinarios y así tener una persona propia al frente del cabildo; el interés del tesorero tenía relación directa con el hecho de tener encomendado el alcalde de "primer voto el conocimiento de la demanda que

(8) Esta amistad no sólo era reconocida por ambos, sino que incluso fue puesta como punto en uno de los interrogatorios, en concreto en el que elevó D. Simón de Monteserín el 8 de septiembre de 1744; allí, en la sexta pregunta se habla de que habían "mantenido desde la Corte de Madrid, donde se conocieron, íntima amistad y recíproca correspondencia"; Araujo, en su declaración de junio de 1744 dijo que se había distanciado días antes de su entrada en Quito.

(9) El conflicto entre Ulloa y Araujo, al que se sumó de inmediato Juan, tuvo comienzo el 30 de enero de 1737, siendo público el apoyo de Valparda -quien incluso llega a aparecer como instigador - a los dos marinos (RAMOS GómEz, vid. [1], págs. 70 y ss. del tomo I). 
sigue contra este Oficial Real [Fernando García Aguado] el licenciado Don Juan de Larrea Zurbano, de la Orden de Calatrava y sus hijos». También acusaba el fiscal a Araujo de no haber considerado y haber ocultado el hecho excluyente de que los nombrados por él eran deudores de la Real Hacienda (10), como le había hecho saber el contador el primero de enero, y de que a él el presidente le había obligado a guardar silencio cuando quiso exponer este asunto en el Real Acuerdo celebrado el 8 de enero, no considerando tampoco las opiniones discrepantes vertidas al respecto.

Estos mismos hechos eran denunciados el 10 de marzo por el Oficial Real contador José Suárez de Figueroa, quien además ampliaba el abanico de acusaciones contra Araujo al añadir otros cargos. Así, por una parte decía que "para disimular el rigor de sus injusticias» había querido introducir el presidente «la odiosa competencia y emulación de las naciones... entre europeos y criollos, debiéndose a la uniformidad en que viven unos y otros el que no haya experimentado la fatalidad a que provoca tan pernicioso cisma» (11); y por otra hablaba del "tirano gobierno que ha introducido las religiones, con grande usurpación de la jurisdicción de sus prelados» (12).

El día 20 de marzo volvió a escribir el fiscal Valparda para denunciar que el presidente había prohibido la libre circulación de correos (13), y había organizado en su casa juegos vetados expresamente por la Audiencia en 1732. Con respecto a la segunda acusación, en el testimonio del escribano Diego Arias Altamirano se leía que en uno de los cuartos del palacio donde vivía Araujo -que eran las casas de cabildo-, precisamente en la pieza habilitada para cuartel de los soldados, entraban «muchas

(10) El problema del voto de los deudores a la Real Hacienda había sido tratado en ocasiones anteriores por la Corona, siendo concluyente lo dispuesto por Carlos II el 10 de agosto de 1689, (Vid. Antonio Muro OrEJón: Cedulario Americano del siglo XVIII, (3 vols.). Sevilla, EEHA, 1956-77, documento número 256 del primer tomo).

(11) Esta acusación de fomentar las parcialidades será lanzada frecuentemente por unos contra otros en cartas o en declaraciones, pero nunca figurará entre las preguntas de los interrogatorios o como una acusación formal.

(12) El 9 de septiembre de 1734 sería acusado formalmente el presidente Araujo por Simón Alvarez de Monteserín de que mediante la entrega de unos dineros dio los correspondientes pases a los religiosos de Santo Domingo propuestos para servir los curatos a cargo de esta religión; este mismo cargo se le hará también con respecto a los Padres Predicadores.

(13) El 8 de marzo de 1737 se prohibía la libre circulación de correos, aduciéndose la necesidad de evitar el ilícito trato y favorecer la remisión de pliegos oficiales; la medida fue aprobada por Villargarcía el 8 de mayo de 1737. 
personas así blancos, mestizos como mulatos, negros esclavos e indios a jugar naipes, dados y otros juegos, por haberse hecho garita formal y pública, y así mismo he sabido, por habérmelo dicho el Teniente de Alguacil Mayor de Corte, que en el juego [de dados y naipes] que tiene armado dicho señor presidente en su mismo cuarto, concurre un sujeto que tiene causas criminales, que hallándose preso asistía a dichos juegos y palacio... [y que ] en dichas garitas amanecen jugando las más de las noches» los que a ellas concurren.

El círculo se cerraba con un nuevo escrito del contador José Suárez de Figueroa, fechado el 2 de junio de 1737, en el que se quejaba este Oficial Real de la prisión que había padecido durante 26 días por orden del presidente. El conflicto había comenzado cuando el contador, para cumplimentar una Real Cédula de 11 junio de 1736 en la que se le urgía abonar una determinada cantidad a los herederos de la Marquesa de Almunia, había entregado a su apoderado - que era precisamente el fiscal Valparda - una libranza contra un deudor de la Real Hacienda, operación que se había realizado sin autorización del tesorero, justificándolo el contador con la afirmación de que aquel dilataba sine die la entrega. Recurrió el tesorero al presidente, quien suspendió de inmediato al contador, le encarceló y le pidió la llave de la Real Caja, lo que también hizo, por medio de un intermediario el Obispo de Quito, quien así se nos pinta como aliado de Araujo; esta operación, según Suárez de Figueroa, tenía como objetivo final el hacerse con los fondos de la Caja Real para comerciar con ellos en Cartagena a través de Juan Antonio Balanzátegui, primo de la mujer del presidente. La carta del contador también aportaba otro dato de interés: la división existente en el interior de la Real Audiencia, donde la actuación del presidente era apoyada por los oidores Don Joseph Llorente y D. Pedro Gómez de Andrade, y atacada por el oidor Don Manuel Rubio de Arévalo y por el fiscal Don Juan de Valparda.

Como vemos, en estos escritos cursados al Rey aparecen una serie de graves extralimitaciones del presidente, como haber actuado en la elección de alcaldes, perseguir a los regidores y prohibir que se les diese testimonio, así como haber levantado una compañía de soldados, financiar su paga con un nuevo impuesto, y haber dado la orden de que se cerrase el libre envío de correos. Pero estos hechos no eran los únicos, pues a ellos había que sumar aquellos otros que hablaban de una peligrosísima línea de actuación de Araujo, como era el haber introducido 
géneros ilícitos, haber montado garitos en su casa, pretender comerciar con los fondos de la Real Hacienda y actuar por soborno, como había sucedido en la elección de alcaldes.

A primera vista todas estas denuncias deben interpretarse o bien como las consecuencias de un desmedido afán de control y lucro del presidente, que no se paraba ante ninguna barrera con el fin de despejarse el camino, o bien como una perfecta muestra de la inhabilidad del mandatario; sin embargo, si analizamos más en profundidad el tema y nos fijamos en las personas y organismos afectados, debemos concluir que en realidad estamos ante una muestra - muy sobresaliente, por cierto- del choque de dos grupos por el poder quiteño: por una parte el que había rodeado o se había visto favorecido por el presidente saliente, y por otra el que iba a servir de sostén o iba a medrar con el presidente entrante. $\mathrm{Si}$ al primer grupo le vemos actuar a través de diversas personas del cabildo, Audiencia, Caja Real o comercio, y podemos identificar rápidamente a sus componentes porque ellos son los firmantes de las quejas, a los integrantes del segundo es más difícil localizarles, porque muchos están tapados por la figura de Araujo, que en ocasiones aparece como el único protagonista, pero que ni está sólo ni actúa en solitario. Si los primeros, asfixiados por el poderoso contrario, se ven obligados a recurrir a Lima o a la Corona con quejas y denuncias que han llegado hasta nosotros, los segundos no generan ninguna documentación que nos permita su inmediata identificación, por lo que sólo les podemos poner rostro viendo quienes chocan con el bando contrario, quienes se ven favorecidos por las disposiciones del presidente, o quienes declaran ciegamente a su favor en las informaciones que entonces se abren, como las relacionadas con la actuación del fiscal Valparda o con el choque con los dos tenientes de navío Don Jorge Juan y Don Antonio de Ulloa.

Pero en este enfrentamiento no sólo aparecen individuos aislados o corporativamente unidos, sino también grupos basados en relaciones de parentesco, que muchas veces constituyen los hilos con los que estaba tejida la tela del poder quiteño. Así, por ejemplo, el fiscal Valparda, en escrito de primero de marzo acusa al tesorero Fernando García Aguado de querer controlar el cabildo a través de la entrada como regidores de "sus yernos, Don Fernando y Don Ignacio Merisalde»; en la misma línea irá parte del escrito de 8 de marzo de los regidores quiteños, quienes declaran que uno de los alcaldes nombrados por Araujo, "Don Tomás Guerrero, está casado con Doña Andrea de Santa Coloma, 
hermana de Doña Paloma de Santa Coloma, mujer de Don Francisco Javier de Larrea, con quien es el litigio que se sufre con el tesorero" Fernando García Aguado; que su hermano Don Pedro de Larrea está casado con otra hija de Don Gaspar de Santa Coloma, y que la mujer del presidente, Doña María Rosa de Larrea era pariente - no se indica en qué grado- de Don Dionisio de Larrea, el padre de Don Francisco Javier y de Don Pedro. Evidentemente el bando contrario no era ajeno a estos entramados, y así sabemos que el fiscal Valparda se había casado en ese año de 1737 con una hija del presidente saliente Dionisio de Alcedo, y que uno de los alcaldes propuestos por el Cabildo en 1737, y rechazado por Araujo, Don Antonio Pastrana, era concuñado del Regidor y Justicia Mayor depuesto Simón Alvarez de Monteserín, siendo este tío de Lorenzo de Nates, diputado del Comercio quiteño y también regidor del cabildo.

Ciertamente estos elementos son muy valiosos para la elaboración de la red del poder local del Quito del momento, pero afortunadamente podemos acercarnos más a la realidad porque la documentación no termina aquí, ya que los acontecimientos se precipitaron y se generaron nuevos datos que también podemos utilizar en ese sentido.

\section{LA ORDEN DE PESOUISA CONTRA ARAUJO DE DICIEMBRE DE 1738}

La explosiva situación vivida en Quito en los primeros meses del año de 1737 había disminuido de tono al asentarse el nuevo grupo y al intervenir el virrey limeño en el restablecimiento del orden. Sin embargo no había sido Lima el único destino de las quejas salidas de Quito, pues, como antes hemos indicado, también la Corona las recibió, pasándolas a manos del Consejo de Indias el 28 de febrero de 1738; este alto organismo las estudió el día 20 de junio, y el 14 de agosto de ese año hizo saber al Rey su opinión al respecto.

En la consulta se aceptaban todas y cada una de las acusaciones hechas contra Don José de Araujo en los escritos antes 
reseñados (14), señalándose el «absoluto y extraño modo de portarse [el presidente], sin atención alguna a las leyes, reales órdenes y a la justicia, valiéndose de la autoridad de su oficio para ultrajar y ofender a los que no condescienden a sus ideas». Por ello y por la urgencia del caso, el Consejo era del parece de «que se despache pesquisa en forma cometida al ministro de la referida Audiencia de Quito o de otra que se de la mayor satisfacción».

A la opinión del Consejo se plegó el Rey el 5 de septiembre (15), fechándose el 31 de diciembre de 1738 dos Reales Cédulas distintas pero interconectadas. En la primera se multaba al anterior presidente de Quito, Dionisio de Alcedo, por haberse inhibido de sus obligaciones - no decomisó la mercancía introducida por Araujo y le dio posesión del cargo a pesar de creerle incurso en un delito tan grave-, y en la segunda se ordenaba que por éste y los otros cargos denunciados (16), se abriese una pesquisa contra el presidente Araujo, quien, en consecuencia, debía ser suspendido del puesto; de la correspondiente actuación se encargó al oidor de Quito Pedro Martínez de Arizala, quien también debía hacerse cargo de la presidencia mientras tuviese validez el nombramiento de Araujo y éste estuviese suspendido.

Si bien el Consejo había obrado rápidamente para intentar

(14) El Consejo no sólo tuvo en sus manos los documentos acusadores, ya que también contó con otros remitidos por Araujo en los que justificaba sus acciones y acusaba al fiscal de la Audiencia; sin embargo no se tomaron en cuenta por considerárseles muy parciales e interesados. (AGI, Quito 110).

(15) AGI, Indiferente General 555 a, fol. 119v.

(16) Estos eran: si era cierto que Araujo introdujo mercadería ilícita en Quito al efectuar su entrada; si continuó teniendo tratos y contratos; si para el nombramiento de alcaldes de 1737 intentó quitar la libertad a los capitulares, contraviniendo la ley $7 .^{\mathrm{a}}$, título 9 , libro 4 y la ley $2 .^{\mathrm{a}}$, título 3 , libro 5 ; si aprobó la nominación hecha por la menor parte aunque se le advirtió que eran deudores de la Real Hacienda; si maltrató de palabra a los siete capitulares que no votaron por los sujetos que propuso; si les negó los testimonios guardando el libro de actas; si suspendió al justicia mayor; si mandó prender al regidor decano; si hizo causa a los escribanos que dieron testimonios a los capitulares, aprisionándolos, multándolos o deponiéndoles; si todo provenía de la influencia del tesorero Don Fernando García Aguado, que tenía interés en que los puestos de alcalde cayesen en gentes de su facción, y a tal fin compró al presidente por 1.500 pesos; si se dejó arrastrar por la actitud del tesorero en la prisión que ordenó contra el contador José Suárez de Figueroa por haber abonado éste 4.600 pesos a los herederos de la Marquesa de Almunia contra un deudor de la Real Hacienda a pesar de haber enterado el contador esas cantidades; si tenía pensado hacerse con el dinero de las Cajas Reales para comerciar en Cartegena por medio de su primo Don Juan Antonio Balansátegui; si publicó bando para que no se despachasen correos contra lo que disponen las leyes 4. ${ }^{\mathrm{a}}$ y 6 . $^{\mathrm{a}}$ del título 16, libro 3 de la Recopilación; si en contra de la 74 y 75, título 16, libro 2, permitió juegos de naipes, dados, etc.; si levantó una tropa y puso una gabela a todos los que tenían tiendas con contrato de pulperías. 
cortar el mal de raíz, sin embargo no pudo alcanzar este objetivo, pues su mandato no se llevó a efecto por haber profesado en la orden franciscana la persona encargada de acometer tan delicada tarea (17), hecho que llevaba aparejado la separación del puesto de oidor $y$, en consecuencia, la imposibilidad de hacerse cargo de la misión encomendada. Así, cuando el 19 de julio le llegó a Pedro Martínez de Arizala la Real Cédula, no pudo ni cumplirla ni trasladar la orden a otra persona, pues no iba señalado ningún suplente; en consecuencia, remitió a Lima los correspondientes pliegos para que el virrey Villagarcía obrase como mejor entendiese, lo que no hizo, pues se inhibió del asunto (18), quedando tan importante tema en dique seco.

A pesar de que la gravedad de los cargos hechos a Araujo y las medidas adoptadas al respecto eran tan excepcionales que los rumores debieron extenderse por los entornos del Consejo, sin embargo nada concreto parece haber llegado a Quito antes de julio de 1739, ya que de este momento sólo hay unos escritos fechados el 20 de abril y el 11 de junio en los que Araujo arremete una vez más contra el fiscal Valparda culpándole de las banderías. Si nada se había filtrado desde Madrid, tampoco nada se supo por mano de Martínez de Arizala, quien reservó para Lima la Real Cédula de 31 de diciembre en la que se destituía al presidente; así, cuando el día 17 de julio de 1739 se abrió en Quito la otra Real Cédula de 31 de diciembre de 1738 -aquélla en la que se multaba a Dionisio de Alcedo con 100 doblones por no haber decomisado las mercancías introducidas ilegalmente por Araujo y haberle dado posesión-, se creyó que esa era la única acusación que tenía pendiente el presidente, la

(17) No podemos descartar que el elemento que decidió finalmente la profesión del oidor fuese, precisamente, el encargo de esta misión, de la que pudo enterarse por sus conexiones en el Consejo. Fuese o no fuese ésta la causa, el hecho es que Pedro Martínez de Arizala, que consideraba su ingreso en la orden seráfica desde 1731, profesó entonces en Pomasqui, como escribió al Rey del 25 de abril de 1739.

(18) El virrey Villagarcía, en escrito al Rey de 14 de enero de 1741 (AGI, Quito 176), dice que había dejado el tema a la voluntad real porque era tal su importancia que no se había atrevido a acometerlo. Nosotros no hemos localizado esta comunicación al Rey, como tampoco la de la notificación al virrey de Santa $\mathrm{Fe}$, a quien Villagarcía dice en este mismo escrito que había trasladado el tema. Teniendo en cuenta la conocida falta de iniciativa el virrey limeño, no podemos dejar de considerar como muy posible la versión que al respecto dio el entonces presidente de Panamá Don Dionisio de Alcedo, quien en su escrito al Rey fechado en Panamá el 25 de junio de 1748, dice que Villagarcía "se encomendó al silencio" (AGI, Quito, 176). 
cual no había trascendido por haber sido cursada secreta y directamente al Rey (19).

Lógicamente, en cuanto Araujo supo la delicada situación en la que se encontraba, procedió a articular su defensa, para lo cual pidió a once escribanos que certificasen «no haber visto, oido ni entendido en dos años y medio que llevo de gobierno que yo hubiese introducido mercaderías en esta ciudad»; solicitó que se abriese una información al respecto en la que treinta testigos propios debían declarar lo que sabían al respecto (20), y consiguió que el cabildo civil y eclesiástico certificaran su buen nombre y obrar, documentos todos ellos que envió a Lima (21) y a Madrid.

Se cierra así una segunda etapa en el procedimiento del presidente Araujo, en la cual debemos inscribir, entre otros, esa serie de documentos antes citados, con los cuales podremos observar con más detalle al grupo que le rodea y detectar posibles variaciones.

\section{LA NUEVA ORDEN DE PESQUISA (1742)}

El que la pesquisa ordenada en 1738 no hubiera podido llevarse a efecto en 1739, no significó que el asunto hubiera sido archivado. Efectivamente, enterado el Consejo de la falta de actuación de Lima, y desconociendo si había obrado Santa $\mathrm{Fe}(22)$, decidió tomar las riendas y en consecuencia el 10 de

(19) El procedimiento empleado por Alcedo fue convertido por Araujo en argumento a su favor en escrito al Rey de 6 de agosto de 1739, en el que decía que así había obrado Don Dionisio porque "conoció que de avisarle al Virrey presto había de aparecer la verdad, y así fraguó este falso informe... desfigurando al verdad" (AGI, Quito 134).

(20) Esta operación del presidente fue, lógicamente, contradicha por el fiscal de la Audiencia, Valparda, una de las cabezas del bando contrario, quien se negó a actuar al respecto; así la tal información fue conducida y llevada a término el 4 de agosto de 1739 por el Fiscal Protector de los Naturales Juan de Luján, que era uno de los partidarios del presidente.

(21) Villagarcía en su escrito al Rey de 14 de enero de 1741 (AGI, Quito 176) se hace eco de estos documentos, pues en él habla de escritos justificativos de Araujo, de informes de "personas de primera fe" y de los cabildos secular y eclesiástico de Quito; también dice que el 23 de junio de 1740 Araujo le remitió "testimonios de los registros que había hecho de sus empleos y equipajes, así en el Puerto del Callao para el de Guayaquil, como en el de Paita".

(22) El Consejo opinó que si el virrey Eslava no hubiera tomado ninguna decisión al respecto, se le debiera hacer cargo de ello, por particular instrucción, a su futuro juez residenciador. 
enero de 1742 propuso al Rey que se reactivase la pesquisa y que se hiciese cargo de ella Don Manuel Rubio de Arévalo, oidor que pertenecía a Santa Fe, a donde había sido trasladado desde la Audiencia de Quito y que en ese momento tenía a su cargo la visita de la Real Caja de este ámbito (23); en segundo y tercer lugar el Consejo propuso a Don Bernardino de La Arbiza y Ugarte y a Don Andrés Verdugo, también de la Audiencia de Santa Fe, todos los cuales fueron nombrados en Aranjuez el 22 de abril de 1742. Se reactivaba así la pesquisa contra Araujo, de la que se encargaba a un oidor que, como reflejó el contador Suárez de Figueroa en su escrito el Rey de 2 de junio de 1737, le era contrario; en ella no sólo debían contemplarse aquellos temas denunciados en 1737, sino también aquellos otros que se le hubieran hecho con posterioridad o se le hicieran entonces, ya que se rodeaban al juez que su misión era «la averiguación de los expresados delitos y excesos que se le imputaban [al presidente] y.de los demás que hubiese cometido desde que entró en la posesión de su empleo hasta el día en que se [le] hiciese saber esta comisión».

Tan grave orden se recibió en Quito el 29 de mayo de 1743, y de inmediato se puso en ejecución, pues el primero de junio era suspendido Araujo del cargo de presidente, y tras ser detenido y secuestrados sus bienes, salía desterrado hacia Tumbez el día 14 para evitar que su presencia interfiriera en la pesquisa, población a la que llegaba el 8 de julio de 1743.

Para entonces los regidores denunciantes ya había afianzado la acusación (24) y los firmantes de los escritos remitidos al Rey habían reconocido sus firmas, a excepción de Don Dionisio de Alcedo, entonces al cargo de la Audiencia de Panamá, y el regidor Jose Hidalgo de Pinto, que había muerto; nadie se retractó de lo entonces enviado a excepción del contador José Suarez de Figueroa, quien no sólo retiró su acusación, sino que en escrito de 4 de agosto justificó plenamente la actuación del presidente Araujo, calificando los hechos por él enunciados en 1737 como errores debidos a las tendenciosas informaciones que le habían

(23) Esta visita comenzó en 1740 y fue consecuencia de los escritos cursados al Rey en 1737.

(24) La correspondiente fianza fue entregada por Don Simón Alvarez de Monteserín, Dun Lorenzo de Nates, don Domingo de Andraca, Don José de Herrera Bernardo de Quirós, Don Lorenzo Díaz de La Madrid, Don Manuel de Salcedo y Oñate como principales, siendo sus fiadores los capitanes Juan Casimiro Navarro, alcalde de segundo voto, y Don Antonio Pastrana. 
dado émulos de Araujo como Simón de Monteserín y Lorenzo de Nates, a quienes acusa de actuar parcialmente con el fin de tener la Justicia a su favor (25).

¿A qué puede deberse este cambio de bando? No sabemos la causa exacta ni el momento, pero es posible que tenga relación con la actuación de Rubio de Arévalo como visitador de la Real Caja, misión de la que se había hecho cargo en 1740 y que no parecía rodar bien para los dos Oficiales Reales; con respecto a este tema es importante señalar que ahora sumaba el visitador un nuevo cargo contra ellos, pues les acusó de haber abonado a Araujo diversas cantidades a pesar de haberse suspendido los pagos en agosto de 1740, con lo cual el presidente depuesto estaba prácticamente al corriente del cobro de su sueldo (26).

\section{LAS PREgUNTAS PRESENTADAS POR DON SimÓN ALVAREZ DE MONTESERÍN Y POR DON JUAN DE VALPARDA}

A requerimiento de Rubio de Arévalo, el 3 de julio de 1743 Don Simón Alvarez de Monteserín presentó las preguntas -más bien declaraciones propias- de su interrogatorio, siete en total, que se centraron básicamente en temas ya argumentados -elección de alcaldes del año 37, persecución de los capitulares y escribanos y destitución del firmante del cargo de justicia mayor-, o relacionados directamente con ellos, como es el caso del conflicto surgido en torno a la elección de alcaldes del año 39 , episodio que nos demuestra que la pugna por el dominio del cabildo quiteño no se había cerrado ni con las elecciones de 1737 ni con posteriores compras de regidurías (27). Pero no todas las preguntas tenían este signo, ya que hubo otras que se centraron en temas con distinto interés, algunas de las cuales tienen relación directa con un aspecto que ya hemos destacado: el de la

(25) En sú escrito dice que "son de una misma familia, casados con tía y sobrina, y... [que pretendian] introducir [como alcalde] a dicho Don Antonio Pastrana con el fin de que llevase adelante sus mal fundados empeños en perjuicio de la causa pública del gobierno económico de esta república, como también por hallarse cargados de haciendas y obrajes, así dentro como fuera de la ciudad, en que están padeciendo sus indios sirvientes muy mal trato y continuas vejaciones y molestias".

(26) En marzo de 1744 se les multó por esta actuación.

(27) La lucha en y por el cabildo quiteño tampoco se cerró ese año, como se desprende de diversas acusaciones y preguntas de posteriores interrogatorios. 
existencia de una red de poder basada en lazos de parentesco. Así, en la cuarta pregunta se inquiere a los testigos «si saben que el dicho Don Tomás Guerrero está casado con Doña Andrea de Santa Coloma, cuñada de Don Francisco y Don Pedro de Larrea, por hallarse esos casados con [las hermanas de aquella] Doña Polonia y Doña Catalina de Santa Coloma, con quienes el dicho Don José de Araujo y su mujer, Doña María Rosa de Larrea, profesan íntima amistad, tratando a dichos Don Francisco y Don Pedro de Larrea de parientes; y [si] el dicho Don Joaquín Laso se halla casado con [Doña Francisca Guerrero], hermana del dicho Don Tomás Guerrero, y [si] ése [Don Joaquín] tiene casada una hija [llamada Doña Luisa] con Don José de Unda, quien es hijo de Don Martín de Unda».

No fue el de Simón de Monteserín el único interrogatorio presentado entonces, ya que el fiscal elevaba el suyo al día siguiente, el 4 de julio; en él, Valparda hacía una serie de preguntas sobre lo denunciado por él en 1737 —elección de alcaldes de 1737, celebración de juegos vetados en casa del presidente, prohibición de remitir correos y levantamiento de una bandera de soldados-, dando una serie de datos que amplían nuestro conocimiento de lo entonces ocurrido (28).

Pero Don Simón Alvarez Monteserín no se conformó con presentar el interrogatorio al que antes hemos aludido, ya que en días siguientes fue desgranando otras preguntas que si bien en algunas ocasiones eran aclaraciones o ampliaciones de las ya formuladas, en otras equivalían a nuevos cargos. Así, por ejemplo, el 22 de julio de 1743 acusaba al depuesto presidente de que

(28) Algunos de estos datos tiene importancia para aproximarnos a la vida y personajes del Quito de entonces, como ocurre con la cuarta pregunta donde se pide a los testigos que digan "si saben que de estos juegos [celebrados en casa de Araujo] resultó la pérdida de caudales que padecieron algunos vecinos, como fueron Don Cristóbal de Troya, Don Tomás Centeno y un fulano Bruselas, y otros, quedando destruidos de medios, y el dicho Don Cristóbal de Troya precisado a vender la tienda de cerería en que se ejercitaba y retirándose de la ciudad por haber consumido en el juego y paga de sus pérdidas todo lo que manejaba".

Otras preguntas, por su parte, amplían otros temas, como ocurre con la sexta, en la que al hablar del pago de los soldados de la compañía que levantó Araujo, no sólo alude al hecho de "imponer a cada pulpero la pensión de cuatro reales cada mes", sino que además "de estos a cada mesa de truco y dueño de ella le impuso la pensión de dos pesos cada mes, que se cobró exactamente, y de que no se pudo librar la mesa perteneciente a la cofradía de las Benditas Animas por más diligencia que hizo Don Nicolás de Sierra, su mayordomo, quien pagó a un criado del capitán de la guardia, como consta del recibo de que hace presentación [este fiscal] con la misma solemnidad. Digan y remítanse a dicho recibo y testimonio los testigos". 
cuando por orden superior estaban cerrados los caminos al tráfico de mercancías, a cambio de diversas sumas había permitido a determinados comerciantes - cuyas declaraciones requería- el paso a Lima de ropas compradas en los galeones fondeados en Cartagena. Esta acusación la reafirmaba y ampliaba el 25 de septiembre, al añadir que «en los primitivos tiempos de la prohibición [de comerciar con Cartagena y sacar las mercancías de Quito], suspendió la publicación del Real Despacho y el correo del Perú por dar lugar a que Don Francisco de Bear y Velasco introdujese a esta ciudad las cargas que traía de la de Cartagena».

El 5 de agosto presentaba el regidor decano Don Simón Alvarez de Monteserín nuevas acusaciones que nos pueden ayudar a aproximarnos a un aspecto muy interesante de la estructura del poder quiteño: el de la relación entre el presidente de la Audiencia y el Cabildo. Así, el 5 de agosto solicitaba Monteserín que se preguntase a los testigos por el local que ocupaban los soldados levantados por Araujo y por la paga del correspondiente capitán -nada menos que Don Pedro de Larrea-, debiéndose inquirir si "para el cuartel de los soldados y compañía que formó dicho señor Don José de Araujo, se desocupó la tienda en que tenía su oficio el escribano público Gerónimo Enrique Capilla, con perjuicio de la pensión conductiva que éste pagaba a las rentas y propios del cabildo, y que para la paga del salario que se le asignó a Don Pedro de Larrea como a capitán de la compañía de dichos soldados se vendieron [en 1737] unas tierras nombradas Miraflores en el egido de Añaquito a Don Manuel del Pino, siendo pertenecientes al bien común" (29). También denunció entonces Monteserín el reparo y reestructuración de las casas del cabildo, donde vivía el presidente por estar arruinado el palacio de la Audiencia, quien también ocupó la casa inmediata, con el «inconveniente de que por la habitación de su persona [en las casas de cabildo] nos hallábamos sin libertad para conferir los públicos expedientes, recelando justamente el que con la inmediación escuchase [desde detrás] de la puerta» las discusiones de los miembros del cabildo.

El 5 de agosto de 1743, Simón de Monteserín presentaba otro cargo en la misma línea ya apuntada: el relativo a que cuando

(29) Según expresa Monteserín en su larga pregunta -más bien declaración-, su actuación y la de sus coaligados hizo que quedaran "libres dichas tierras para el uso común y pública utîlidad, no sólo de los circunvecinos, sino del comercio de las provincias que se comprenden desde Cartagena hasta esta ciudad". 
estaban ausentes los alcaldes ordinarios, el presidente no daba la vara a quien le correspondía, que era el regidor decano - precisamente el acusador-, sino a quien se le antojaba, incluso a personas ajenas al propio cabildo, hecho que había sucedido en los años 40 y 42 . A los cuatro días, D. Simón añadía un nuevo cargo: el mal obrar en el reparto de las semanas de carnicerías, diciendo que Araujo «incitado de sus particulares utilidades ha tenido intervención en el repartimiento de dichas semanas, dándolas en oposición a los privilegios del cabildo a sus aliados y a los que se han manifestado más obsequiosos", sin que las reclamaciones hechas a la Audiencia prosperasen por ser su voluntad fiel a la del presidente. Que esto había provocado que muchos criadores hubiesen dejado de tener ganados, ya que temían que no se les concediesen semanas, lo que había sido causa de que la ciudad hubiese estado desabastecida en algunas ocasiones.

El 12 de agosto el regidor decano volvía al lejano 1737 y acusaba a Araujo de que el 23 de febrero de ese año había prohibido interesadamente la tenencia y fabricación de aguardiente de caña; que lo había hecho no con el fin de salvaguardar la salud pública (30), sino con el de upoder vender con reputación y excesiva ganancia los que introdujo a esta ciudad en las cargas que condujo al tiempo que vino a servir su presidencia, [por lo que] duró la tenaz prohibición de que se fabricasen aguardientes en esta provincia [poco tiempo, pues se eliminó] en cuanto acabó de expender los que había introducido" (31).

(30) Araujo se apoyó en una Real Cédula de 10 de agosto de 1714, aún vigente, y en que su consumo ocasionaba "muertes repentinas... particularmente en los indios, con peligro manifiesto de la salvación de sus almas y con subción de los dichos indios", hecho causado por "su mala calidad... [por ir mezclada] con cabuya y otros ingredientes que la hacen más nociva". Esta medida fue aprobada por el virrey limeño el 8 de mayo de 1737.

(31) No fue éste el único caso en el que el depuesto presidente aparece mezclado con actividades comerciales realizadas en éste o en posteriores momentos; así, Don Lorenzo de Nates le acusó de estar mezclado en ellas, como demostraba un recibo de dos mil pesos a favor de Don Juan de Zumárraga, y de utilizar para ello el servicio de correos, llegándose a requerir a Don Diego Enríquez, Correo Mayor, para que "manifieste los libros de apuntes de encomiendas que se han remitido por los chasquis".

También diversos comerciantes acusaron a Araujo de actividades comerciales, denunciando, por ejemplo, que había invertido dinero en Cartagena a través de Don Francisco Rodayegua; que las mercancías así adquiridas habían entrado en Quito bajo el nombre de Tomás de Valencia, y habían pasado luego al presbítero don Juan de Zumárraga, quien dejó su venta por temor a la reprimenda del Obispo. 


\section{EL INTERROGATORIO GENERAL ELABORADO POR EL PESQUISIDOR RUBIO DE ARÉVALO}

La ininterrupida presentación de preguntas y de listas de testigos para contestarlas obligó al juez pesquisidor Don Manuel Rubio de Arévalo a disponer el 18 de agosto de 1743 que se elaborase un interrogatorio único al que contestase la generalidad de los testigos. Este cuestionario lo hizo público el juez el 2 de octubre de 1743, y constaba de 29 preguntas en las que se recogían las acusaciones vertidas contra el suspendido presidente, de las cuales ya nos hemos ocupado (32), así como una final -la 29- en la que se pedía a los testigos que hiciesen pública cualquier otra falta cometida por Araujo mientras estuvo desempeñando su puesto.

Tres de los cargos recogidos por Rubio de Arévalo en el interrogatorio general por él elaborado tenían relación directa con actividades comerciales realizadas o permitidas ilegalmente por el presidente. Así, en la segunda pregunta se inquiría por la introducción del año 36 y por si Araujo "en el tiempo de su oficio haya continuado tratos y empleos por sí o por interpósitas personas»; en la 15 por si la prisión decretada en 1737 contra el contador fue por complacer al tesorero o por apoderarse de los fondos de la Caja Real para que el primo de la esposa de Araujo, Don Juan Antonio Balanzátegui, trajera ropa de Cartagena y la 23 por permitir el paso de comerciantes a Cartagena y a Lima cuando estaban cerrados los caminos.

Esta última pregunta es especialmente interesante por estar intimamente relacionada con el especial momento vivido por Quito a causa de la guerra con Inglaterra de 1739-1748. En efecto, los ataques ingleses contra el istmo de Panamá y las amenazas de la flota de Anson sobre las costas del Pacífico, por una parte hicieron que permanecieran en Cartagena los productos que debían haberse negociado en la prevista feria de Portobelo,

(32) En el interrogatorio de Rubio de Arévalo se recogen dos acusaciones presentadas por Monteserín a las que no hemos hecho mención expresa en las páginas anteriores. La primera - pregunta 11 - tiene relación directa con la suspensión de Monteserín de la vara de Justicia Mayor, pues se trata de la prohibición decretada por Araujo de que aquel publicara ef estanco de barajas decretado en Lima en diciembre de 1737. La segunda - pregunta 28- es sobre si el presidente se había beneficiado en dos reales por cada libra de pólvora comprada para remitir a Guayaquil cuando se pensaba que esta ciudad iba a ser atacada por los barcos del almirante Anson. 
y por otra obligaron a que los fondos de la Real Hacienda y de los comerciantes que habían llegado a Panamá en la Flota del Mar de Sur, fuesen trasladados - vía Guayaquil- a Quito, en donde entraron hacia el 9 de agosto de 1740.

Esta presencia de los comerciantes y de los caudales limeños en Quito planteó un problema que no había sido considerado por las autoridades virreinales: la actividad de estos forasteros aprovechándose del permiso concedido a los quiteños para trasladarse a Cartagena y comprar allí directamente, y no en la feria de Portobelo, las mercancías que necesitasen. A este derecho de los quiteños (33) se apuntaron también algunos de los peruleros, unos y otros en muchos casos con la intención última de pasar a Lima las cargas - legales o ilegales (34) — adquiridas en Cartagena, iniciándose así una relación directa galeonista-comerciante que si no se cortaba impediría la celebración de la prevista feria (35). Con este fin, el virrey de Santa Fe, Don Sebastián de Eslava, el 25 de septiembre de 1470 ordenó al presidente de Quito que impidiese que sobrepesasen la ciudad una serie de «sujetos del comercio de Lima que con despacho de los oficiales de Cartagena han conducido mercaderías hasta la provincia de

(33) Esta posibilidad había sido ejercida por algunos comerciantes quiteños antes de octubre de 1737, según nos cuenta Dionisio de Alcedo, en su "Aviso Histórico". vid. Justo ZaRAGOzA (editor): Piraterias y agresiones de los ingleses y de otros pueblos de Europa en la América española desde el siglo XVI al XVIII deducidas de las obras de D. Dionisio de Alsedo y Herrera publicadas por..., Madrid, 1883, pág. 250.

(34). Evidentemente, junto a mercancías legales entraron otras de ilícito comercio, hecho que incluso reconoce el virrey Villagarcía en su exigua relación de gobierno, donde dice que los caudales tomados por el Almirante inglés Anson en Paita el 24 de noviembre de 1741 estaban en relación directa con ese tipo de mercancías, y puntualiza que "la ocasión de la ropa que se traía de Cartagena como de buena entrada y con guías de las Cajas Reales de Quito, fue capa de los fraudes; pero ésta es rara especie de culpa, donde el que la maldice rehúsa calificarla con su deposición, y los que por su utilidad quebrantan las leyes, murmuran de su inobservancia; y resulta una pública voz sin testigo que judicialmente la apruebe, y una queja en que los mismos quejosos impiden con su silencio su remedio" " Relación de Gobierno del Excelentísimo Señor Don Antonio José de Mendoza Camaño y Sotomayor, Marqués de Villagarcía", firmada en Lima el 24 de junio de 1745. Biblioteca Nacional (Madrid), manuscrito 3.107, fol. $13 \mathrm{v})$.

(35) La celebración de la feria en algún punto distinto del desmantelado Portobelo - Honda era el lugar que parecia más idóneo- recibió el definitivo golpe de gracía al llegar noticias de que a la Mar del Sur pasaban varios navíos de registro franceses, que fondeaban en Montevideo el 13 de junio de 1742 y en febrero de 1743 estaban ya en Valparaiso. Tras una serie vana de propuestas y proyectos, la idea de celebrar una feria fue definitivamente desechada el 26 de agosto de 1744. 
Quito» (36), así como que «hasta tanto que reciba expresas órdenes de los referidos Señor Virrey [de Lima] y Presidente de Panamá sobre la facultad de internar efectos, negará V.S. el paso a las cargas» que se condujeran a Quito.

Esta orden del virrey de Santa Fe era publicada en Quito el 28 de noviembre de 1740, pero al parecer no fue cumplida rigurosamente, ya que a Araujo se le acusó de que a cambio de dineros y presentes había autorizado el paso de diversas personas con mercancías antes de que fuese levantada la prohibición (37); esta actuación fue causa de que el comisario del Comercio del Perú en Quito, Manuel Laviano, abriese entonces la correspondiente investigación contra el presidente Araujo, la cual, por cierto, se fue enriqueciendo con otros capítulos referente a temas relacionados con el comercio y los comerciantes limeños (38).

A pesar de que, como acabamos de señalar, la iniciativa para investigar el tema de los pases dados por Araujo a determinados comerciantes había partido del consulado limeño, la documentación generada no fue de su exclusivo uso, porque cuando Don Manuel Rubio de Arévalo supo de la actuación del comisario Laviano, pidió a éste que le entregase las pruebas y declaraciones que obraban en su poder para sacar copia y adjuntarlas al proceso que él conducía y en el que existía ese cargo contra Araujo (39). Por esta causa esta acusación corrió desde entonces por doble mano: por la de Rubio de Arévalo y por la de la cabeza del comercio limeño.

(36) Los comerciantes limeños eran Don Antonio de Villar, Don Juan Manuel de Heraso, Don Gerónimo Lozano y Don Diego de Rivera y Mendoza.

(37) La probihición no duró mucho tiempo, ya que el 12 de enero de 1741 se tomaba en Lima un Real Acuerdo que comunicó Villagarcía el día 14 de enero, por el cual se había concedido "licencia para que se condujesen las ropas cuyas facturas venían configuradas desde ese reino a diversos particulares de éste, trayendo las guías necesarias y pagando los reales derechos" (AGI, Lima 1489).

(38) Los diversos desafueros del presidente Araujo contra los comerciantes limeños, centrados especialmente en su obrar con respecto a sus contribuciones monetarias extraordinarias, fueron causa de que el 25 de marzo de 1741, éstos comunicaran a la Audiencia que "tienen a Vuestra Señoría... por odioso y sospechoso para el conocimiento de todas y cualesquiera causas... y recusan a Vuestra Señoría para que se sirva de abstenerse de dichas sus causas".

(39) Rubio de Arévalo solicitó esta documentación el 12 de octubre de 1743, pero no la consiguió hasta el 8 de noviembre, una vez que venció la lógica resistencia de Manuel Laviano. 


\section{EL CAMBIO DE SIGNO EN EL PROCESO CONTRA DON JOSÉ DE ARAUJO}

Aunque el no haber profundizado aún lo suficiente en el proceso que venimos analizando nos impide conocer el papel exacto que jugaba el fiscal de la Audiencia, Don Juan de Valparda, en la estructura de las fuerzas quiteñas, sin embargo creemos que su persona era una de las figuras destacadas en el bando de los opositores al presidente Araujo, por lo que no puede resultar extraño que el poder de este grupo se viese muy afectado por la muerte del fiscal, ocurrida en septiembre de 1743 tras una corta enfermedad comenzada en el mes de julio de ese año.

Sin embargo nada parece indicar que se produjese una alteración de fuerzas ni en ese año ni en los comienzos del siguiente, en concreto hasta abril y mayo de 1744, meses en los que a Araujo se le hacían dos nuevos cargos que abrían dos nuevos procesos que iban a correr también por mano del oidor Rubio de Arévalo, aunque en forma independiente a aquel del que nos venimos ocupando.

El primer cargo se le hizo el 17 de mayo de 1744 por mano de Don Antonio Pastrana, quien acusó formalmente a Araujo de haberle desplazado a finales de 1737 del oficio de Colector General de las Rentas Decimales. Este asunto no era nuevo, pues había comenzado a correr cuando Don Antonio Pastrana escribió al Rey en 1738 quejándose de su injusta remoción del puesto, operación en la que veía la larga mano del presidente Araujo; así lo consideró también el Consejo, que falló a favor del querellante el 11 de diciembre de 1742. Si la sentencia le era positiva ¿a qué podía deberse que en este momento demandase Pastrana a Araujo por una cuestión aparentemente resuelta? Sin duda a una filtración llegada a oídos del removido relativa a que el brazo eclesiástico no tenía la intención de obedecer la orden de reposición dada por el Consejo (40), hecho que se confirmó plenamente cuando el 1 de junio de 1744 el correspondiente escrito llegó oficialmente a Quito. Así, antes de que el brazo eclesiástico pudiese llevar a efecto su resolución, Pastrana interpuso su demanda ante Rubio de Arévalo, juez que le era claramente favorable.

El segundo proceso se le abrió a Araujo el 2 de junio de 1744,

(40) Otra posibilidad al respecto -que nosotros consideramos poco probable- es que Pastrana hubiera perdido las esperanzas de que el alto organismo emitiera sentencia. 
y fue consecuencia de las reclamación hecha por Don Francisco Javier Piedrahita, albacea del deán difunto Pedro de Zumárraga, a quien Araujo debía la cantidad de dos mil pesos. La petición del pago se basaba en un documento presentado por Lorenzo de Nates en los inicios del proceso contra Araujo - julio de 1743como prueba de que el presidente, mientras ejercía su cargo, estaba mezclado en tratos y contratos; se trataba de un recibo fechado el 16 de mayo de 1738 en el que Araujo reconocía que había recibido «del Señor Doctor D. Juan de Zumárraga 2.000 pesos que por hacer una merced me ha prestado, los cuales entregaré a su disposición cuando me los pida, o se irán satisfaciendo del producto de 40 petacas de jabón, 19 botijas de aguardiente y 15 fardos de cordobanes que [yo, José de Araujo] pongo a su disposición para que la persona que señale venda estos géneros y le entregue el producto».

Aunque el inicio de estos dos nuevos procesos parece indicar un empeoramiento de la situación en la que se encontraba el depuesto presidente Araujo y el consiguiente refuerzo del grupo de los demandantes, en realidad estamos ante la situación contraria, ya que los hechos demuestran que el poder de sus partidarios había aumentado tanto que sus contrarios se vieron obligados a acumular esos cargos para buscar el pronunciamiento favorable de un juez de su partido.

Esta idea se apoya en los tres hechos siguientes ligados directamente con el proceso o con sus actores. El primero es la petición hecha a la Audiencia el 16 de junio de 1744 por parte de los Oficiales Reales de Quito en la que solicitaban la recusación de Rubio de Arévalo tanto en la visita de las Cajas Reales que había comenzado el 17 de mayo de 1740 cuando aún era oidor de Quito, como en cualquier otro proceso que tocase a los Oficiales Reales o a sus familias (41), lo que les concedió la Audien-

(41) La petición del contador y del tesorero se basaba en que la visita, "pudiéndola tener acabada [Rubio de Arévalo] muchas veces, la había tenido iniciada y abierta, y en odio de los Oficiales Reales pretendía actuar en ella cuando se hallaba más ocupado que nunca con aquella presidencia y gobierno y con la prolija comisión de causa de capítulos contra D. José de Araujo". Por las razones dadas para que se aceptase la recusación de Rubio de Arévalo, sabemos que éste había tenido un enfrentamiento con el contador a causa del cobro de su salario, ya que aquel no le abonó la cantidad que le correspondía como oidor de Santa Fe porque estaba ordenado "que lo que en una Caja se deba, no se pague en otra, y que no se cumplan los libramientos de los virreyes contra leyes expresas"; tampoco le concedió cantidad alguna por cuenta del salario de presidente, porque no constaba el título de tal ni estaba copiado en los libros reales; tampoco se le pudo asignar - como pretendía Rubio de Arévalo- el sueldo que le correspondía a Araujo, porque estaba expresamente prohibido que el sueldo del pesquisado lo cobrase el pesquisidor. 
cia (42). El segundo dato que debemos considerar en este apartado es el hecho de que Don Simón Alvarez de Monteserín, el 8 de septiembre de 1744 presentase a Rubio de Arévalo un interrogatorio sin firma de abogado porque urecelosos de que les puedan sobrevenir algunas vejaciones y molestias, ningún abogado se atreve a firmar dicho interrogatorion.

A estos dos datos que acabamos de enunciar hemos de añadir un tercero ajeno al proceso en sí mismo, aunque muy conectado con él, pues es la causa de los dos anteriores: el nombramiento de un nuevo presidente de Quito. Efectivamente, a fines de 1744 terminaba el período de mandato de Araujo, por lo que la presidencia podía ser ya ocupada por aquella persona a quien el Rey hubiera concedido el cargo, la cual necesariamente debía desplazar del puesto a Rubio de Arévalo, quien sólo tendría ya en su mano la pesquisa contra Araujo. Si este cambio necesariamente era visto con intranquilidad por los demandantes, su postura se transformó en temor cuando supieron que el 27 de junio de 1744 - tras intensas gestiones (43) - el Rey nombraba para el puesto a Don Fernando Félix Sánchez de Orellana, el hijo de Pedro Javier Sánchez de Orellana, Marqués de Solanda, ambos destacados «araujistas».

El vuelco, pues, no podía ser más absoluto.

\section{LAS PREgUNTAS PRESENTADAS POR DON JOSÉ DE ARAUJO Y LAS ELEVADAS POR DON SIMÓN ALVAREZ DE MONTESERÍN EN SEPTIEMBRE DE 1744}

La orden de destierro a Tumbes del depuesto presidente Araujo tocó a su fin el 28 de enero de 1744, día en el que se le concedió que pasase a Guaranda, donde recibió la orden de 28 de mayo de 1744 para que se trasladase a Quito, a donde llegó el 12 de junio; el día 15 comenzó su declaración, que concluyó a los diez días. Apoyándose en ella, en las contestaciones de los

(42) Aunque la Audiencia falló a favor de los demandantes el 22 de junio, Rubio de Arévalo hizo caso omiso de la sentencia, ya que continuó con la vísita y procedió a la suspensión de los dos oficiales.

(43) La operación para hacerse con el cargo no fue tan simple, ya que la persona inicialmente nombrada - tras la entrega de 26.000 pesos- fue el peruano D. Miguel Goyeneche; sin embargo éste no desempeñó el puesto, pues ejerció su derecho a traspasarlo, lo que hizo a Don Pedro Javier Sánchez de Orellana, Marqués de Solanda, quien a su vez lo cedió su hijo Don Fernando Félix Sánchez de Orellana, de 29 años, natural de Latacunga, quien era nombrado para el cargo el 27 de junio de 1744, vid. GonZález SuÁREZ [1] 1970, págs. 1.069 y ss. 
testigos y en las pruebas presentadas, Antonio de La Muela, en nombre de los capitulantes, pedía el 22 de julio la condena de Araujo; éste, por el contrario, el 15 de agosto se declaraba inocente de los cargos del proceso general y de los que le habían sustanciado Piedrahita y Pastrana, presentando para su descargo diversos instrumentos y un interrogatorio fechado el día 17 que estaba formado por 35 preguntas a las que debían responder los testigos que él solicitase.

Las preguntas comprendidas entre la segunda y la séptima tratan de la entrada de las cargas del equipaje del año 36 y de las acusaciones que se le habían hecho a Araujo sobre haber comerciado por sí o por interpósitas personas en los años siguentes; la séptima es sobre la bajada de comerciantes quiteños a Cartagena en el año 37 y sobre las ventas efectuadas por ellos en Quito; la octava sobre el incidente con Don Antonio de Ulloa y Don Jorge Juan, al cual achaca el haberse visto en la necesidad de levantar una compañía de soldados; la novena y décima sobre la gabela impuesta a los pulperos y a los truqueros, tocándose en la 27 el tema de la venta de las tierras de Miraflores; la 11 sobre el despacho de correos; la 12, 13 y 14 sobre juegos en su casa y sobre los arruinados en ellos, citándose expresamente a Don Cristóbal Troya, Don Tomás Centeno, y un fulano Calderón conocido por Bruselas. La 15, 16, 17 y 27 sobre la elección de alcaldes de 1737; la 18 y 19 sobre la enemistad de Valparda y sus acciones; la 20, 21 y 22 sobre las elecciones de alcaldes de 1739; la 23 sobre su acutación contra el Contador en 1773; la 24 y 25 sobre la prohibición del aguardiente de caña; la 26 sobre el genio litigoso de Monteserín y sus ansias por dar la vara a su cuñado Antonio Pastrana; la 27 sobre los reparos efectuados en las Casas de Cabildo, donde residía; la 31 y 32 sobre el repartimiento de semanas de carnicerías y la 33 sobre el nombramiento de visitadores de trapiches. El interrogatorio se cerraba con las preguntas 34 y 36, en las que Araujo inquiría a sus testigos sobre su actuación como presidente con respecto a "cohechos... [o] baratería en las votaciones de pleitos, en las providencias de gobierno [o] de la administración del vicepatronato", enumerando uno tras otro aquellos temas de los que era acusado por sus contrarios, desde comerciar por interpuestos a suspensión de sentencias, pasando por el tema de la provisión de curatos.

A este interrogatorio general añadió Araujo preguntas sueltas o enlazadas para ser contestadas por individuos determinados. Entre estas cuestiones no pueden faltar las relativas a los temas de parentesco, y así el 16 de octubre pidió que se preguntase a los escribanos «si Don Juan Navarro y su hijo don Juan Navarro 
Monteserín han sido Alcaldes Ordinarios los tres años consecutivos de 742, 743 y 744, y si Don Simón de Monteserín es concuñado de Don Juan Navarro y tío por su mujer de Don Juan Navarro Monteserín, y si Don Lorenzo de Nates está casado con prima hermana de Don Juan Navarro Monteserín».

El 8 de septiembre de 1744, Don Simón de Monteserín presentaba un nuevo interrogatorio para que use examinen los testigos que nuevamente presentaré y se ratifiquen» en sus declaraciones, planteando en él una serie de cuestiones relacionadas con las acusaciones que hemos venido viendo, e incluso con los roces existentes entre personas de los dos grupos en litigio. A este respecto podemos destacar la pregunta que se hace a los testigos sobre las causas del enfrentamiento entre el suspendido presidente Araujo y el difunto fiscal de la Audiencia Juan de Valparda o la referencia que se hace al inicio del enfrentamiento entre dos personas destacadas de ambos bandos: Don José de Barba y Don Antonio Pastrana, inquiriéndose por el litigio «sobre la propiedad y posesión de unas aguas que corrían al molino de una hacienda del dicho Don Antonio [Pastrana], sobre que tuvieron una gran discordia, de donde dimanó amistad capital». A este interrogatorio general hay que sumar una serie de preguntas dirigidas a personas concretas o a colectivos como el de los escribanos o los que fueron soldados, entre las cuales no podía faltar el tema de los parentescos (44).

\section{LAS TACHAS DE LOS TESTIGOS}

Si bien las acusaciones expuestas en los interrogatorios, los instrumentos que las avalan, las listas de testigos llamados a declarar y sus respuestas, son aportaciones fundamentales para averiguar hechos y conexiones, también hay otros tipos de elementos que tienen especial interés para nuestro propósito: por una parte los datos personales de los testigos (45), y por otra las

(44) Así se pregunta si "la esposa de dicho señor Don Alvaro Navia Bolaño [-oidor de la Real Audiencia de Lima-], que fue prima hermana de la referida señora Doña María Rosa de Larrea [-la esposa del depuesto presidente-], de cuyo matrimonio nació el dicho Maestre de Campo" del Puerto del Callao Don Antonio Navia Bolaño, testigo fundamental de Araujo en el tema de la introducción de mercancías del año 36.

(45) Dado' el tipo de cargos que se le hicieron a Araujo, fueron muchos los testigos llamados por las partes, y de muy variopinta procedencia, por lo que el estudio de sus datos personales permitíá aproximarnos a ese angulo de la sociedad quiteña. 
tachas que las partes aducen a los testigos contrarios para así anular los cargos o las pruebas basadas en sus declaraciones. Con respecto a este último tema es cierto que en todos los interrogatorios se plantearon preguntas que directa e indirectamente tenían esa intencionalidad, pero también lo es que en el presentado por Araujo el día 17 de agosto - al que acabamos de referirnos en el apartado anterior - la finalidad no puede ser más obvia.

Efectivamente, en la pregunta 28 Araujo solicita a sus testigos que informen de la pertenencia de determinados declarantes (46), a la facción contraria, que según él había estado encabezada por el fiscal de la Audiencia, fallecido en septiembre del año anterior, quien había sido íntimo amigo de los regidores que le habían acusado. Péro la pregunta no se queda sólo en la mera lista de los reprobables, ya que señala las causas del por qué eran acérrimos enemigos suyos, lo que acrecienta considerablemente su valor; así, por ejemplo, dice que «a Don Francisco Piedrahita le embaracé la venta en cincuenta pesos de unos indios enfermos que por cobrar los tributos que administraba los enviaba vendidos a una hacienda en dicha cantidad. El Señor Marqués de Maenza no concurrió al donativo que hizo esta ciudad para Cartagena y le dije a su padre Don Gregorio Mateu que así lo informaba a Su Majestad, y ha sido por esto multado en mil pesos (47), y sirvió en su casa, y fue mucho tiempo familiar de ella Don Lorenzo de La Madrid, uno de mis capitulantes»; o que "a fray Domingo Laso no le quise hospedar en mi casa cuando vino a esta ciudad,

(46) La pregunta rezaba: "Y si saben que Don Diego Preciado, Don Juan de Saldumbide, Don Francisco Villasis, Don Jacinto Torres, Don Agustín Saldavia, Don Nicolás Sierra, Don Alonso Ballinas, Don Juan de Uriarte, Don Esteban Alava, Don Antonio Bahamonde, Don Francisco Piedrahita, el Señor Marqués de Maenza, Don Francisco de Villasis y Velasco [-este nombre aparece subrayado-], Don Cristóbal Medrano, fray Domingo Laso [y] Don Antonio Pastrana fueron todos éstos íntimos amigos de dicho Señor Fiscal, concurriendo a todas horas en su casa y juntándose para paseos y para lo demás que supieren. Y si todos los referidos son también íntimos amigos de los regidores que me han capitulado. Digan y den razón".

(47) El virrey de Santa Fe, por carta de 21 de junio de 1740, pidió 50.000 pesos al comercio y al vecindario de Quito para la defensa de Cartagena. El presidente Araujo, en su escrito al Rey de 18 de diciembre de 1740 señalaba que sólo había podido conseguir 10.320, pero que "es cierto que algunos miles más se hubieran recogido si el Marqués de Maenza hubiera concurrido a este préstamo a proporción de su conocido caudal, pero se excusó totalmente... y en una visita que me hizo su padre Don Gregorio Mateu, me dio a entender que los nobles no estaban obligados a estas contribuciones"; en el mismo sentido obraron los comerciantes limeños, ya que no dieron cantidad alguna a pesar de que se les había repartido 38.000 pesos. Casos contrarios fueron -entre otros que enumeralos del Marqués de Solanda y del diputado del Comercio D. Antonio Muñiz, que contribuyeron generosamente; ambos, por supuesto, eran destacados "araujistas". 
ni menos empeñarme para que le dieran el curato que me pidió de la Punta de Santa Helena».

Por su parte, el 22 de noviembre de 1744, D. Simón de Monteserín presentaba un escrito sobre la parcialidad de los testigos de la parte contraria, en donde se alegan cuestiones de parentesco (48) u otros datos que aluden a la estructura del poder y al entramado de servicios, pagos y deudas pendiente entre los miembros de aquella sociedad. Así, por ejemplo, de Don Pedro y de Don Tomás Fernández Salvador preguntaba el regidor decano a sus testigos si «son y han sido benefactores de dicho señor Don José, prestándole dinero y obligándose al que le suplió el Ilustrísimo Señor Obispo por instrumento público, como fiadores de dicho señor Don José, en cuya remuneración repartió [éste] distintos años las boletas de semanas de carnicerías a elección y arbitrio de los susodichos, adjudicándoles la mayor y mejor parte de las semanas del año, con injuria de los demás criadores de ganados y dueños de potreros, a que se añade que han sido gratificados por dicho Señor Don José, pues consta de sus mismas declaraciones que les regaló parte de aquellos mismos afectos que [en 1736] introdujo a esta ciudad para su expendio, de que se colige claramente la íntima amistad que profesa con los susodichos». Del Padre Maestro fray Francisco Javier Enríquez, de la orden de Nuestra Señora de La Merced, y del Teniente del Correo Mayor, Don Diego Enríquez, su padre, preguntaba a los testigos si "son amigos íntimos de estrecha relación y mutua correspondencia con dicho señor Don José, quien a dicho padre maestro lo ha preferido en las semanas de las carnecerías, dándole superabundantes y las mejores semanas del año sin tener hacienda de potreros, y en su correspondencia ha cooperado Don Diego Enríquez, Teniente de Correo Mayor, en remitirle por los chasquis las encomiendas y empleos de dicho señor Don José para la ciudad de Lima, y estando beneficiados y coaligados con

(48) Así, por ejemplo, preguntaba el regidor decano a sus testigos por el puesto que tenía la familia de próximo presidente de la Audiencia en la red del poder quiteño, diciendo que si era de público conocimiento que "el señor Marqués de Soldano es enemigo capital mío, de toda mi familia y de mis partes; amigo intimo y parcial de señor Don José de Araujo y hermano del general Don Juan José Sánchez, quienes son primos hermanos de Don Clemente Sánchez y los dos últimos están casados con dos hijas de Don Eugenio Chiriboga y de Doña María de Luna, y son concuñados de Don Tomás Guerrero por haber casado éste de primer matrimonio con Doña Rosalía de Chiroboga, y de segundo con Doña Andrea de Santa Coloma, hermana de Doña Polonia, Duña Catarina y Doña Nicolasa de Santa Coloma, mujerles] legítimals, respectivamente,] del comisario Don Agustín Sándoval, [de] Don Franciseo y [de] Don Pedro de Larrea, quienes públicamente han corrido y corren por parientes de la señora Doña María Rosa de Larrea, esposa del dicho señor Don José, con tal intimidad que han sido y son inseparable de su casa". 
dicho señor, no deben ser admitidos por testigos en la misma causa, en que han sido favorecidos y cooperantes».

El 5 de diciembre, Don Simón Alvarez de Monteserín entregaba un nuevo interrogatorio destinado a probar la fiabilidad de sus testigos -en total 54, de los que 36 eran comerciantes de Quito, Cartagena y Lima- y las tachas de los del contrario, basándose en los mismos elementos que antes vimos. De los datos que se aportan, creemos que deben destacarse las tirantes relaciones de Monteserín con la familia del que iba a ser el próximo presidente de Quito, sobre las cuales debe preguntarse a los testigos "si saben que el señor Marqués de Solanda, el Maestre de Campo Don Fernando Sánchez, su primogénito [y] el gobernador Don Clemente Sánchez son mis enemigos capitales por la controversia que se formó, con grave escándalo de la república, en esta Santa Iglesia Catedral la cuarta dominica de cuaresma de este presente año en los edictos de natema sobre querer ser preferido dicho Señor Marqués, como Corregidor, al Tribunal de la Santa Inquisición y a mí como Alguacil Mayor que soy del Santo Oficio. Y si el dicho señor Marqués, con todos sus parientes y hermanos, como lo es el general Don Juan José Sánchez y los arriba referidos, con Don dicho Tomás Guerrero, cuñado de los dichos Don Juan y Don Clemente Sánchez y del Padre Maestro fray José de Chiriboga, por haber casado de primer matrimonio con Doña Rosalía de Chiriboga, mantienen pública parcialidad y conspiración con dicho señor Don José, frecuentando su casa de día y noche. Digan, etc.».

Si en esta pregunta Monteserín ponía tachas al inmediato presidente de Quito y a su familia, en la 13 inquiría por otra de las figuras quiteñas claves: el obispo Andrés de Paredes, cuya parcialidad hacia Araujo había aflorado en 1737 en la carta escrita por el contador José Suárez de Figueroa el día 2 de junio de 1737, y a quien se habían hecho indirectas alusiones en posteriores documentos. Así, ahora pedía que se interrogase a los testigos por «si saben que el Ilustrísimo Señor Obispo es íntimo amigo de dicho señor Don José, su paisano y protector en esta causa y [en] todas las que se le ofrecen. Y si el dicho doctor Don Diego Riofrío y Don Gaspar Fajardo son familiares de dicho Ilustrísimo Señor, y si el referido Riofrío es primo de Don Clemente Sánchez y tiene estrecho vínculo de amistad con todos los de la facción y parcialidad del señor Don José y Don Gaspar Fajardo es su paisano. Y si el doctor Don Antonio Viteri médico racionero de esta Santa Iglesia es hijo legítimo de Don Lorenzo Viteri y, por eclesiástico, sujeto [al] Ilustrísimo Señor Obispo. Digan, etc.». 
Don José de Araujo, por su parte, no dejó pasar la ocasión que la ley le brindaba para tachar a los testigos contrarios de parciales o a sus informaciones de inconsistentes, presentando los correspondientes interrogatorios sobre las tachas de los testigos en los días 26 de noviembre y 4 de diciembre de 1744, fecha esta última en la que también pedía que se preguntase a las personas que iba a presentar, si las 51 que había llamado como testigos eran idóneas, sin enemistad con la parte contraria ni parentesco con su persona. Desafortunadamente para nosotros los argumentos que utiliza para descalificar a los testigos de la parte contraria son menos "profundos" que los de Monteserín, si bien también nos ilustran sobre algunos aspectos de la realidad quiteña del momento.

Así, por ejemplo, y dejando aparte las alusiones a la amistad o enemistad, Araujo pide que se desestime el testimonio de Don Ignacio Cagueñas por "ser [éste] sujeto fácil y fabricante de ideas valiéndose de cartas falsas que escribe para divulgarlas, de que se ha cogido en esta ciudad el común dicterio de que en oyendo alguna novedad extraña la desacreditan con decir que "es de las de Cagueñas" " (49); el de Silvestre Chavarría porque "lo trajo el general Don Diego de Navia de su cocinero» (50), o el de «Cristóbal Troya [que] ha sido tahur público, que no ha tenido nunca el menor caudal, [que es] de muy bajo nacimiento y vicioso conocido en la bebida del aguardiente" (51).

\section{LOS EPISODIOS FINALES}

El pleito había llegado ya a su recta final, y así el 8 de febrero de 1745 los capitulares hacían su alegato de "bien probado», manteniendo sus acusaciones, el cual era respondido por Araujo

(49) Monteserín salió en defensa de su testigo, de quien dice "que el que haya formado algunas ideas sin daño de tercero en lo jocoso, no arguye que en lo individual haya quebrantado la fe del juramento, mayormente siendo un sujeto de relevante nobleza y de rectos modales".

(50) Dice Monteserín: "no denota otro fundamento que el de la temeraria censura, con que se pretende disminuir la persona del dicho Don Silvestre con el apodo de cocinero, que no lo es ni lo ha sido nunca, pues el que por curiosidad sepa disponer algunas viandas, que se han descrito en libros que corren impresos y gue por diversión los leen las personas de la mayor recomendación, no le influye título tan bajo".

(51) Dice Monteserín "que tuvo tres haciendas, casa libre de censos, y esclavos y una tienda, muy cuantiosa, de cerería, y que todos estos bienes los consumió en los juegos de la dicha casa [de juegos] de Don José, de donde sacó el vicio de tahur público". 
el 23 de marzo; también por entonces se veían las demandas de Pastrana y Piedrahita, que quedaban vistas para sentencia, respectivamente, el 15 de enero y el 17 de abril. Pero mientras esto sucedía, se hacía efectivo el nombramiento de Don Fernando Félix Sánchez de Orellana, natural de Latacunga (52), quien tomaba posesión del puesto de presidente de la Real Audiencia de Quito el 15 de marzo de 1745 (53). Con la entrada de Don Fernando como presidente se consolidó definitivamente el poder del grupo que rodeó a Araujo, quien por su parte vio mejorada considerablemente su situación, ya que además del apoyo de los Oficiales Reales; de los oidores Don Pedro Gómez de Andrade y Don Esteban de Oláis y Echevarría, y del fiscal Don Juan de Luján (54); del corregidor y del Obispo de Quito, contó también con el del nuevo presidente, cuyo nombre y el de su familia había sido reiterademente mencionado a lo largo del pleito, como hemos visto.

Pero no sólo contó Araujo con el apoyo de Quito, ya que también Lima respondió a sus espectativas (55) mediante un Real Acuerdo de 16 de septiembre de 1745. A esta ciudad se había trasladado el expresidente quiteño tras haber hecho fuga de Quito con toda la documentación del pleito y pareceres favorables de todos los poderes: presidente de la audiencia, cabildo secular, Obispo, cabildo eclesiástico, y cabezas de las distintas órdenes religiosas (56); la base jurídica alegada por Araujo para que se le amparase en el recurso que hacía al Consejo de Indias por la omisión de su juez en dar sentencia, era que había transcurrido más de tres meses desde la conclusión de la causa sin

(52) Vid. [43].

(53) Fernando Sánchez de Orellana al Rey, Quito 16 de marzo de 1745 (AGI, Quito 134). Los oidores de la Audiencia eran Don Pedro Gómez de Andrade, Don Esteban de Oláis y Echevarría y Don José de La Quintana.

(54) Alcedo y Herrera, en escrito al Rey fechado en Panamá el 25 de junio de 1748, acusó particularmente a estas personas (AGI, Quito 176).

(55) Contra lo acordado en Lima vertió muy duras palabras el expresidente de Quito Don Dionisio de Alcedo y Herrera en su escrito al Rey fechado en Panamá el 25 de junio de 1748. En él señalaba el peso de Araujo en la Audiencia de Lima, "cuna de su nacimiento, pues no es menester más comprobante para conocer que los ministros de aquella Audiencia procedieron con total afección y pasión ... que haber incluido en la consulta al oidor Don Pedro Bravo de Ribero, habiendo sido éste su testigo en la pesquisa, y los demás haberse ladeado a influjos de Don Alvaro de Navia Bolaño, Oidor Decano de aquella Audiencia, pariente y testigo del pesquisado, a [la] que concurrió su cuñado Don Victorino Montero, quien fue el que seseptó las cargas [de ilícito comercio transportadas por Araujo de la Nueva España] en la ciudad de Piura [cuando era corregidor de aquella demarcación], y [que] hoy se halla de Capitán de la Guardia de Virrey del Perú" (AGI, Quito 176).

(56) Están fechados entre el 10 y el 24 de junio de ese año. 
que se hubiera hecho público el fallo, indicando que lo primero había sucedido el 23 de marzo de 1745.

Araujo salió hacia Chile el 3 de diciembre de 1745, en uno de cuyos puertos embarcó en navío que le condujo a Madrid, donde ya estaba el día 14 de noviembre de 1746. El 7 de diciembre de ese mismo año presentaba en la Sala de Gobierno del Consejo un memorial sobre su caso, que pasó al Fiscal el 20 de febrero, una vez que fue desestimada la cuestión previa de si había de esperarse a la sentencia del pesquisidor -que se falló en Quito el 4 de marzo de 1746-, dándose el 15 de abril de 1747 sentencia condenatoria. Sin embargo, visto en la Sala de Justicia, y realizadas nuevas diligencias, el 9 de julio de 1747 dio el Consejo sentencia favorable al acusado, haciéndola firme el Rey el 8 de agosto de ese año de 1747.

En consecuencia se dieron como temerarias falsas, injustas y calumniosas las acusaciones hechas contra Araujo, y a cinco de los regidores del cabildo de Quito que escribieron la carta de 8 de marzo de 1737 -Don José Pinto, Don Manuel Salcedo, Don Lorenzo de La Madrid, Don Domingo de Andraca y Don José de Herrera- se les condenó a la suspensión de sus empleos y a otro cualquier oficio de justicia, y a los otros dos regidores -Don Lorenzo de Nates y Don Simón de Monteserín-, que estaban mezclados en otras acusaciones, a privación perpetua de sus oficios y a obtener cualquiera de justicia o de los honoríficos de la República. A Don José Suárez de Figueroa, contador, a cuatro años de suspensión, y a una multa. A varios testigos, que se consideraron falsarios, a diversas multas, e incluso a destierro. A Don Dionisio de Alcedo al pago de 10.000 pesos, 4.000 para la Corona y 6.000 para Araujo. Al juez Manuel Rubio de Arévalo, por parcialidad e irregularidades en el desarrollo de la causa, se le suspendía del oficio de oidor por ocho años (57).

\section{EPÍLOGO}

Como hemos señalado en diversas ocasiones en este artículo, el proceso contra el presidente de la Audiencia de Quito Don José de Araujo y Río no debe verse como un problema particular

(57) Con esta sentencia no se cerraba todo el conjunto de acusaciones, ya que el 18 de octubre de 1747 se le comunicaba a Araujo el fallo condenatorio pronunciado en Quito el 9 de enero de ese año sobre la acusación de los comerciantes limeños acerca de los agravios y perjuicios sufridos. También se abrieron, como es lógico, los recursos de los condenados. 
de ese mandatario, sino como una consecuencia de la lucha por el poder en ese ámbito. Evidentemente el estudio del pleito en general y de los cargos en particular ilumina con muy buenas luces aquel momento quiteño, pero también nos permite aproximarnos a cuestiones menos tangibles y más profundas, como puede ser la identificación de las personas que constituyen los bandos enfrentados, la articulación de alianzas, los puestos y organismos por los que y desde los que se pugna, los objetivos que persiguen unos y otros, los premios que obtienen, etc., etc.

Con el estudio de estos temas nos acercaremos a los fines y a la estructura de los grupos de poder de aquella sociedad quiteña de los años cuarenta del siglo XVIII, así como a sus conexiones con los de los ámbitos vecinos, uno de cuyos representantes era el limeño José de Araujo, quien merced al dinero y a sus influencias obtuvo el puesto de presidente de la Audiencia de Quito. 